Canadian Journal of Plant Science Revue canadienne de phytotechnie

\title{
AAC Whitestar great northern dry bean
}

\begin{tabular}{|c|c|}
\hline Journal: & Canadian Journal of Plant Science \\
\hline Manuscript ID & CJPS-2016-0209.R1 \\
\hline Manuscript Type: & Cultivar description \\
\hline Date Submitted by the Author: & 12-Sep-2016 \\
\hline Complete List of Authors: & $\begin{array}{l}\text { Balasubramanian, Parthiba; Agriculture and Agri-Food Canada, } \\
\text { Muendel, Hans-Henning } \\
\text { Chatterton, Syama; Agriculture and Agri-Food Canada, } \\
\text { Conner, Robert; Agriculture and Agri-Food Canada, Research } \\
\text { Hou, Anfu; AAFC, }\end{array}$ \\
\hline Keywords: & $\begin{array}{l}\text { AAC Whitestar, high yield, large seed size, partial field resistance to white } \\
\text { mould }\end{array}$ \\
\hline
\end{tabular}


Balasubramanian et al. - AAC Whitestar great northern dry bean

\author{
CULTIVAR DESCRIPTION
}

\title{
AAC Whitestar great northern dry bean
}

P. M. Balasubramanian ${ }^{1,3}$, H.-H. Mündel ${ }^{1,4}$, S. Chatterton $^{1}$, R. L. Conner ${ }^{2}$, and A. Hou ${ }^{2}$

${ }^{1}$ Agriculture and Agri-Food Canada, Lethbridge Research and Development Centre, P.O. Box 3000, Lethbridge, Alberta, Canada T1J 4B1; ${ }^{2}$ Agriculture and Agri-Food Canada, Morden Research and Development Centre, Unit 101 Route 100, Morden, Manitoba, Canada R6M 1Y5; received accepted

${ }^{3}$ To whom correspondence should be addressed. E-mail: parthiba.balasubramanian@agr.gc.ca ${ }^{4}$ Retired 
Balasubramanian et al. - AAC Whitestar great northern dry bean

Balasubramanian, P., Mündel, H.-H., Chatterton, S., Conner, R. L., and Hou, A. 2016. AAC

Whitestar great northern dry bean. Can. J. Plant Sci. 96: xxx-xxx. AAC Whitestar is a high yielding great northern dry bean (Phaseolus vulgaris L.) cultivar with an upright, indeterminate bush (Type IIb) growth habit, large seed size and partial field resistance to white mould. AAC Whitestar was developed at the Agriculture and Agri-Food Canada (AAFC) Research and Development Centre, Lethbridge, AB. AAC Whitestar is suitable for irrigated wide row production in Alberta and Saskatchewan.

Key words: AAC Whitestar, high yield, large seed size, partial field resistance to white mould AAC Whitestar is an upright great northern dry bean (Phaseolus vulgaris L.) cultivar with high yield, large seed size and partial field resistance (avoidance) to white mould caused by Sclerotinia sclerotiorum (Lib.) de Bary. It was developed at the Agriculture and Agri-Food Canada (AAFC) Research and Development Centre, Lethbridge, AB. AAC Whitestar was tested in the Short Season Wide Row Irrigated Dry Bean Cooperative Registration Trials in Alberta and Saskatchewan from 2012 to 2014, and registered on 20 May 2016 (Registration no. 8010), at the Variety Registration Office, Canadian Food Inspection Agency, Ottawa, ON.

\section{Pedigree and Breeding Methods}

AAC Whitestar, tested as L10GN821, was derived from the cross L04E494/Resolute made at the AAFC Lethbridge Research and Development Centre in 2005. L04E494 was an advanced great northern bean line from AAFC-Lethbridge. Resolute was a great northern dry bean cultivar developed by AAFC and registered in 2004 (Mündel et al. 2005). Resolute was selected as a 
Balasubramanian et al. - AAC Whitestar great northern dry bean

parent for its lodging resistance, early maturity and avoidance of white mould when grown under irrigation in southern Alberta and Saskatchewan. AAC Whitestar was developed by modified pedigree breeding. The $F_{1}$ plants of the cross were grown in a greenhouse at Lethbridge in summer 2006, and the $F_{2}$ seeds were increased in the greenhouse in fall 2006 and bulk harvested. The $\mathrm{F}_{3}$ bulk populations were grown at Lethbridge and Vauxhall, AB in 2007 and single plant selections were made based on upright indeterminate bush growth habit, early maturity and great northern bean seed traits (size, shape and colour). In the $\mathrm{F}_{4}$ plant row nursery at both locations in 2008, single plant selections were made again based on growth habit, early maturity and great northern bean seed traits. Progeny-row yield was added to the selection criteria in the $\mathrm{F}_{5}$, which was conducted in 2009 as a Modified Augmented Design (MAD type 2) (Lin and Poushinsky 1985). The row length of the single-row plots in the $\mathrm{F}_{5} \mathrm{MAD}$ yield trial was $5 \mathrm{~m}$ with a $60 \mathrm{~cm}$ spacing between rows. AAC Whitestar was tested as L10GN821 in wide row $(60 \mathrm{~cm})$ Preliminary $\left(\mathrm{F}_{6}\right)$ Yield Trials with three replications at Lethbridge and two replications at Vauxhall, AB in 2010. However, the trial at Lethbridge was lost due to waterlogging. AAC Whitestar was tested in both the wide row $(60 \mathrm{~cm}$ row spacing) and narrow row $(23 \mathrm{~cm}$ row spacing) Pre-Cooperative $\left(\mathrm{F}_{7}\right)$ Yield Trials with four replications at Lethbridge and Vauxhall in 2011. Based on seed yield and quality, lodging resistance, early maturity and indeterminate bush growth habit, AAC Whitestar was advanced to the Short Season Wide Row Irrigated Dry Bean Cooperative Registration Trials from 2012 to 2014, which were grown at Lethbridge, Vauxhall and Bow Island, AB and Outlook, SK. In the Cooperative Registration Yield Trial, plots consisted of four rows with a row length of $5 \mathrm{~m}$, and the experimental design was a lattice with four replications. AC Resolute was used as a check cultivar in the early generation nurseries and 
Balasubramanian et al. - AAC Whitestar great northern dry bean

AAC Tundra (Balasubramanian et al. 2012) was used as a check cultivar in the Preliminary, PreCooperative and Cooperative Registration Yield Trials.

Two hundred pods were randomly selected from AAC Whitestar plants grown in the seed increase nursery at Vauxhall in 2013. The pods were hand-threshed individually and seeds ( $\left.\mathrm{F}_{10}\right)$ with size, shape and colour appropriate for a great northern bean market class were selected. The seeds were grown in the greenhouse at Lethbridge in winter 2014 and the plants were harvested individually. After examining the seed $\left(\mathrm{F}_{11}\right), 24$ progeny-rows were planted at Twin Falls, Idaho in summer 2014. The progeny rows were bulked and this $F_{12}$ seed formed the first breeder seed.

\section{Performance}

YIELD: In the Short Season Wide Row Irrigated Dry Bean Cooperative Registration Trials grown at nine station-years, AAC Whitestar averaged $3.85 \mathrm{t} \mathrm{ha}^{-1}$, which was similar to the check cultivar AAC Tundra $\left(3.70 \mathrm{t} \mathrm{ha}^{-1}\right)$ (Table 1). The Cooperative Registration Yield Trial at Lethbridge in 2014, and the trials at Vauxhall in 2012 and 2014 were not included in the statistical analysis due to high CV (> 20\%).

MATURITY: AAC Whitestar had an average maturity of $98 \mathrm{~d}$ over the 12 station-years, which was the same as the check cultivar AAC Tundra (Table 1).

SEED WeIGHT: The average seed mass of AAC Whitestar over 12 station-years was $39.8 \mathrm{~g} 100$ seeds $^{-1}$, which was significantly higher than AAC Tundra (36.9 g). Large seed size in the great northern bean market class is preferred in certain markets especially in the Mediterranean region. LODGING: At maturity, AAC Whitestar had lodging resistance similar to AAC Tundra (2.3 vs. 2.6) on a scale of $1=$ upright to $5=$ plants with weak stem and prostrate growth (Table 1 ). 
Balasubramanian et al. - AAC Whitestar great northern dry bean

\section{Other Characteristics}

GROWTH HABIT: AAC Whitestar has an indeterminate bush (Type IIb) growth habit (Brick and Johnson, 2004) with long vines, similar to AAC Tundra. Average plant height of AAC Whitestar was $52 \mathrm{~cm}$ and AAC Tundra was $46 \mathrm{~cm}$.

FLOWER AND SEED: AAC Whitestar has a white standard and wing petals, and a white seed coat, similar to the check cultivar.

DiSEASE REACTIONS: AAC Whitestar has partial field resistance (avoidance) to white mould, similar to AAC Tundra. The white mould disease incidence of both AAC Whitestar and AAC Tundra was $31 \%$ (Table 1). The white mould disease severity of AAC Whitestar and AAC Tundra was also the same (1.8). AAC Whitestar is susceptible to races 73 and 105 of anthracnose, caused by Colletotrichum lindemuthianum (Sacc. \& Magnus) Briosi \& Cav.; and common bacterial blight, caused by Xanthomonas axonopodis pv. phaseoli (Smith) Vauterin et al. (Vauterin et al. 1995); syn. X. campestris pv. phaseoli (E.F. Smith) Dye, as is the check cultivar AAC Tundra (data not shown).

PROCESSED SEED QUALITY: A composite seed sample from four replications of AAC Whitestar and the check cultivar AAC Tundra harvested at each location (Lethbridge and Bow Island, AB and Outlook, SK in 2014) were subjected to both cooking and canning quality tests. Both cultivars were similar for cooking and canning quality traits (Table 2).

\section{Maintenance and Distribution of Pedigreed Seed}

Breeder seed of AAC Whitestar will be maintained by the AAFC Lethbridge Research and Development Centre, Lethbridge, AB. AAC Whitestar has been released on an exclusive basis 
Balasubramanian et al. - AAC Whitestar great northern dry bean

for seed production and marketing to Viterra Inc., $2802-5^{\text {th }}$ Avenue North, Lethbridge, AB, T1H 0P1, where pedigreed seed may be purchased.

The financial support provided by Viterra, Alberta Pulse Growers Commission, Alberta Crop Industry Development Fund, Alberta Innovates - Bio Solutions and AAFC Agri-Science Clusters is gratefully acknowledged. The authors thank C.R. Daniels, T. Reid, G. Kereliuk and R.S. Erickson at Lethbridge, and W.C. Penner and D.B. Stoesz at Morden for their technical assistance. The authors would also like to thank D.T. Tomasiewicz, D.L. David and G. Hnatowich at the Canada-Saskatchewan Irrigation Diversification Centre, Outlook, SK for performing the Cooperative Registration Trial.

Balasubramanian, P. M., Mündel, H.-H., Conner, R. L. and Hou, A. 2012. AAC Tundra great northern dry bean. Can. J. Plant Sci. 92: 1403-1405.

Brick, M. A. and Johnson, J. J. 2004. Classification, development and varietal performance. Pages 7-13 in H. F. Schwartz, M. A. Brick, R. M. Harveson, and G. D. Franc, eds. Dry bean production and pest management. 2nd ed. Bulletin 562A. Colorado State University, University of Nebraska, Lincoln, NE, and University of Wyoming, Laramie, WY, USA.

Lin, C.S. and Poushinsky, G. 1985. A modified augmented design (type 2) for rectangular plots. Can. J. Plant Sci. 65: 743-749.

Mündel, H. -H., Kiehn, F. A., Huang, H. C., Conner, R. L. and Saindon, G. 2005. Resolute great northern bean. Can. J. Plant Sci. 85: 393-395.

Vauterin, L., Hoste, B., Kersters, K. and Swings, J. 1995. Reclassification of Xanthomonas. Internat. J. System. Bacteriol. 45: 472-489. 
Balasubramanian et al. - AAC Whitestar great northern dry bean

Table 1. Mean of agronomic and disease traits of the great northern bean cultivar AAC Whitestar and the check cultivar AAC Tundra grown in Alberta and Saskatchewan from 2012 to 2014.

\begin{tabular}{lcccccc}
\hline Cultivar & $\begin{array}{c}\text { Yield } \\
\left(\mathrm{t} \mathrm{ha}^{-1}\right)\end{array}$ & $\begin{array}{c}\text { Maturity } \\
(\text { days })\end{array}$ & $\begin{array}{c}\text { Seed weight } \\
\left(\mathrm{g} \mathrm{100} \mathrm{seeds}{ }^{-1}\right)\end{array}$ & $\begin{array}{c}\text { Lodging resistance }^{a} \\
(1-5 \text { scale })\end{array}$ & \multicolumn{2}{c}{ White mould $^{b}$} \\
\cline { 5 - 6 } AAC Tundra & 3.70 & 98 & 36.9 & 2.6 & 31 & Severity $(1-4)$ \\
AAC Whitestar & 3.85 & 98 & 39.8 & 2.3 & 31 & 1.8 \\
LSD $^{c}$ 0.05 & 0.33 & 2 & 1.4 & 0.3 & 15 & 0.5 \\
Station-years $^{a}$ & 9 & 12 & 12 & 11 & 3 & 3 \\
\hline
\end{tabular}

${ }^{a}$ Lodging resistance is determined at maturity using a 1 to 5 scale, from $1=$ upright plants, $3=$ partially upright plants to $5=$ plants lodged due to weak stem.

${ }^{b}$ White mould incidence refers to the mean percentage of plants with symptoms in the inoculated disease nursery at Lethbridge from 2012 to 2014 . White mould severity is assessed using a 1 to 4 scale, where $1=$ healthy plants, $2=$ plants have one infected branch or pod, $3=$ plants have multiple infected branches or pods, and $4=$ main stem is girdled or plants are dead.

${ }^{c}$ Least significant difference, $P \leq 0.05$, calculated from a pooled error term of all entries common to the respective three years in the Short Season Wide Row Dry Bean Cooperative Registration Trial. 
Balasubramanian et al. - AAC Whitestar great northern dry bean

Table 2. Mean of cooking and canning quality traits of the great northern bean cultivar AAC Whitestar and the check cultivar AAC Tundra grown in Alberta and Saskatchewan in 2014.

\begin{tabular}{|c|c|c|c|c|c|c|c|c|}
\hline \multirow[b]{2}{*}{ Cultivar } & \multicolumn{2}{|c|}{$\begin{array}{l}\text { Cooking quality - } \\
\text { Hard seed }(\%)^{a}\end{array}$} & \multicolumn{6}{|c|}{ Canning quality } \\
\hline & $\begin{array}{l}\text { Before } \\
\text { cooking }\end{array}$ & $\begin{array}{c}\text { After } \\
\text { cooking }\end{array}$ & $\mathrm{HCS}^{b}$ & $\mathrm{HCB}^{c}$ & $\begin{array}{c}\text { Drain } \\
\text { weight }(\%)^{d}\end{array}$ & $\begin{array}{l}\text { Matting } \\
(1 \text { to } 4)^{e}\end{array}$ & $\begin{array}{l}\text { Appearance } \\
(1 \text { to } 4)^{f}\end{array}$ & $\begin{array}{l}\text { Texture }(\mathrm{kg} \\
\text { force })^{g}\end{array}$ \\
\hline AAC Tundra & 3.9 & 0.4 & 2.3 & 2.4 & 58.4 & 2.0 & 1.8 & 28.1 \\
\hline AAC Whitestar & 6.5 & 0.9 & 2.3 & 2.5 & 59.5 & 1.8 & 2.0 & 30.4 \\
\hline $\mathrm{LSD}_{0.05}$ & 4.6 & 1.1 & 0.1 & 0.1 & 2.5 & 1.0 & 0.8 & 3.1 \\
\hline
\end{tabular}

${ }^{a}$ Two hundred seeds per genotype per location were soaked in de-ionized water at room temperature for $16 \mathrm{~h}$ and cooked for $20 \mathrm{~min}$ at $97^{\circ} \mathrm{C}$. Percentage hard seed was determined before and after cooking.

${ }^{b}$ Hydration coefficient after soaking (HCS): Eighty-six grams of great northern bean seed was soaked for $16 \mathrm{~h}$ in de-ionized water at room temperature. Hydration coefficient after soaking was determined as: seed weight after soaking / weight of dry seed.

${ }^{c}$ Hydration coefficient after blanching (HCB): Soaked seed was blanched for 3 min at $93^{\circ} \mathrm{C}$. Hydration coefficient after blanching was determined as: seed weight after blanching / weight of dry seed.

${ }^{d}$ Drain weight (\%): Bean seeds were processed at $116^{\circ} \mathrm{C}$ for $45 \mathrm{~min}$ in brine. Can content was weighed and the weight of bean seed was determined after washing in tap water on a 8-mesh screen (Tyler series) positioned at a $15^{\circ}$ angle. Percentage drain weight was determined as: (weight of bean seed / weight of can content) $* 100$

${ }^{e}$ Matting (clumping) of seeds was assessed on a 1 to 4 scale, where $1=$ none, $2=$ trace, $3=$ slight and $4=$ moderate.

${ }^{f}$ Appearance of seeds was assessed on a 1 to 4 scale, where $1=$ excellent, $2=$ good, $3=$ acceptable, and $4=$ unacceptable.

${ }^{g}$ Texture (Firmness) (kg force $100 \mathrm{~g} \mathrm{seed}^{-1}$ ) was determined by placing $100 \mathrm{~g}$ of washed drained bean in to a standard shear compression cell (CS-1) of Texture Measurement System - Touch (TMS-Touch, Food Technology Corp., Sterling, VA) and shearing them using a load cell of $255 \mathrm{~kg}$-force at a rate of $0.83 \mathrm{~cm} / \mathrm{sec}$. 